\title{
ASSESSING SEISMIC RISK IN RETFALA NOVA, OSIJEK
}

\author{
Maja Galista \\ Josip Juraj Strossmayer University of Osijek, Faculty of Civil Engineering Osijek, mag.ing.aedif. \\ Marijana Hadzima-Nyarko \\ Josip Juraj Strossmayer University of Osijek, Faculty of Civil Engineering Osijek, Assistant Professor \\ Corresponding author: mhadzima@gfos.hr
}

\begin{abstract}
The Croatian territory, as part of the Mediterranean-trans-Asiatic belt, experiences pronounced earthquake activity. Seismic risk is the expected damage caused by earthquakes to buildings, measured both in social and economic losses, which can be described through seismic hazard, seismic vulnerability, and exposure. The city of Osijek is located in the eastern part of Croatia, and Retfala Nova is a residential settlement in the western part of the city. An important step in assessing earthquake loss is defining the exposure, so we created a form used to collect information on buildings and make a building database. In this paper, we estimated seismic vulnerability based on the capacity spectrum method, which involves constructing fragility curves and converting them to damage probability matrices, as well as constructing capacity curves.
\end{abstract}

Keywords: Seismic risk, seismic vulnerability, fragility curves, building typology

\section{PROCJENA POTRESNOG RIZIKA OSJEČKOG NASELJA RETFALA NOVA}

Sažetak: Područje Republike Hrvatske, kao dio mediteransko-transazijskog pojasa, odlikuje se izraženom potresnom aktivnošću. Potresni rizik predstavlja očekivani stupanj oštećenja građevina nakon potresa. Može se jednostavno opisati kroz četiri elementa: potresnu opasnost, potresnu oštetljivost, izloženost zgrada, te socijalne i ekonomske gubitke. Grad Osijek nalazi se u istočnom dijelu Republike Hrvatske. Retfala Nova je stambeno naselje smješteno u zapadnom dijelu grada. Budući da je bitni element u procjeni potresnog rizika izloženost, predložili smo obrazac koji će služiti kod stvaranja baze zgrada grada. U ovome radu potresna oštetljivost procijenjena je pomoću metode zasnovane na spektru sposobnosti nosivosti, koja podrazumijeva konstruiranje krivulja vjerojatnosti oštećenja i njihovu pretvorbu u matrice vjerojatnosti oštećenja, te konstruiranje krivulja sposobnosti nosivosti.

Ključne riječi: potresni rizik; potresna oštetljivost; krivulje vjerojatnosti oštećenja; tipologija zgrada 


\section{INTRODUCTION}

Over ten million earthquakes occur around the world each year, causing immense economic and social loss to individuals, communities, and businesses. A key way to reduce these losses is to identify and manage seismic risk.

Seismic risk is the expected level of damage caused to buildings by an earthquake. It is defined as the probability that the social and economic consequences of the earthquake will exceed a particular value at a particular site or area over a specified period, expressed in monetary value or number of casualties (dead and wounded). Assessing seismic risk and loss from earthquakes involves many disciplines and usually involves assessing the components shown in Figure 1: hazard, exposure, vulnerability, and economic and social losses [1].

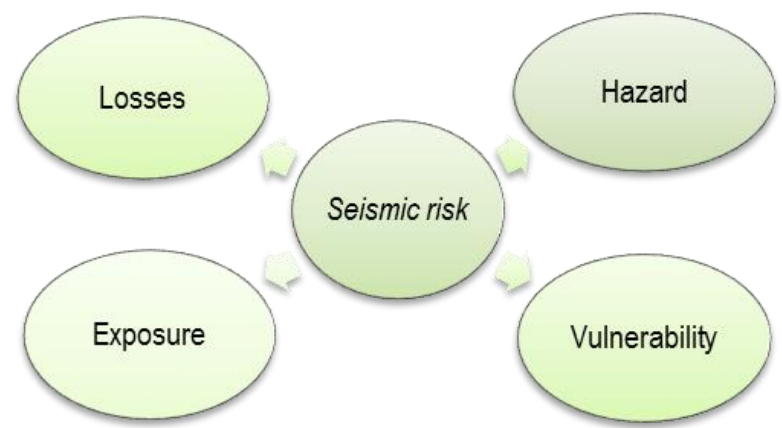

Figure 1 Basic components of seismic risk

In this study, we assessed the earthquake damage to buildings in Retfala Nova, Osijek-which we chose because of the available, complete documentation of the buildings under consideration-for several intensity levels, using fragility curves to assess their seismic vulnerability.

The capacity spectrum method $[2,3]$ was developed to analyze structural vulnerabilities and has emerged as a standard tool for assessing building loss. This method, often referred to as the HAZUS methodology, has been adopted worldwide, but has not been adapted. However, the capacity curves and fragility functions have been calibrated to the considered building stock [4]. For example, Kircher et al. [5] described the various modules of the Hazard-United States (HAZUS) Earthquake approach and summarized their key concepts. Molina and Lindholm [6] assessed the seismic risk in Oslo. Lantada et al. [7] analyzed the seismic risk in urban areas of Barcelona using two current-generation methods: a vulnerability index method and a capacity spectrum method. Their results were consistent with the historical and modern evolution of the populated area, showing the validity and strength of both methods. Recently, Boukri et al. [8] provided predicted the seismic risk and damage for buildings in Constantine, Algeria, adapting their methodology of assessing building damage from the HAZUS approach.

\section{EXPOSURE}

When assessing how earthquakes impact a building, it is important to know the building's structure and its behavior under stress from previous earthquakes in the area, the engineering standards adopted during its construction, and the positions and distribution of sensitive buildings nearby [1].

Buildings and facilities can be catalogued into taxonomical classes to make a building inventory. This inventory serves as input data for calculating losses and requires various pieces of information on buildings such as their purpose, date of construction or retrofit, height, occupancy, value, and location. Several building typologies and taxonomies exist, prominently including ATC - 14 (1987), EMS - 98 (1998), Risk - UE (2004), HAZUS - MH (FEMA, 2006), PAGER - STR (2008), and SYNER - G (2011) [9]. Any taxonomy, however, is a compromise between simplicity and thoroughness.

Before creating a building inventory for Osijek, the pertinent data for these buildings must be defined. The data collection form for these buildings considers the attributes given by the Global Earthquake Model (GEM) building typology [10]. The GEM typology describes a building using 13 properties which might affect seismic 
performance: direction, material of the lateral load-resisting system, lateral load-resisting system, height, date of construction or retrofit, occupation, building position within a block, shape of the building plan, structural irregularities, exterior walls, roof, floor, and foundation system. Figure 2 shows an example of the completed form for one building in Retfala Nova. Details on current typologies around the world, the main properties necessary for assessing seismic vulnerability, and conclusions on the proposed properties in the form can be found in [11].

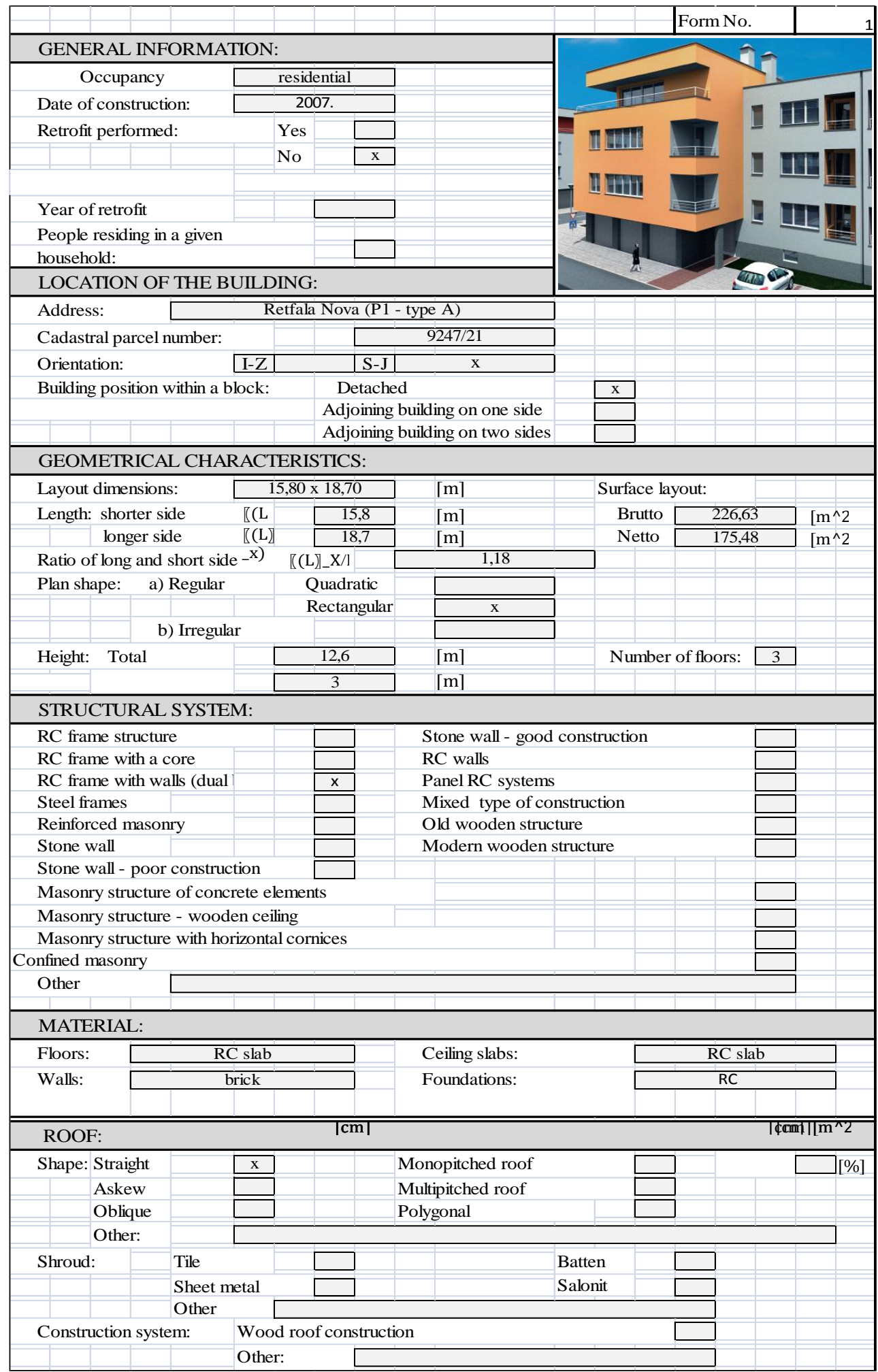

Figure 2 Example form for collecting data on a building [11] 


\section{STUDY AREA}

Retfala Nova is a complex of residential buildings in western Osijek, consisting of 20 urban villas holding 160 apartments. This part of Osijek has a satisfactory urban infrastructure and is well connected by transport to the city center [12].

The residential buildings in this settlement were built in 2007. There are five types of buildings (A, B, C, D, and $\mathrm{E}$ ), and four buildings of each type. Table 1 shows the characteristics of each building type. The buildings have a rectangular layout, and their load-bearing structures are built entirely of reinforced concrete [12].

Table 1 Characteristics of buildings in Retfala Nova, Osijek

\begin{tabular}{cccccccc}
\hline Object name & $\begin{array}{c}\text { Date of } \\
\text { construction }\end{array}$ & $\begin{array}{c}\text { Base Dimensions } \\
{[\mathrm{m}]}\end{array}$ & $\begin{array}{c}\text { Height } \\
{[\mathrm{m}]}\end{array}$ & $\begin{array}{c}\text { Number of } \\
\text { stories }\end{array}$ & $\begin{array}{c}\text { RC shear wall } \\
\text { area in shorter } \\
\text { direction }\left[\mathrm{m}^{2}\right]\end{array}$ & $\begin{array}{c}\text { RC shear wall } \\
\text { area in longer } \\
\text { direction [m²] }\end{array}$ & $\begin{array}{c}\text { Structural } \\
\text { system }\end{array}$ \\
\hline A & & $15.80 \times 18.70$ & 12.60 & 4 & 6.44 & 2.96 & \\
B & & $13.80 \times 17.00$ & 14.00 & 4 & 2.22 & 4.42 & Frame with RC \\
C & 2007 & $14.20 \times 18.20$ & 14.00 & 4 & 2.85 & 4.48 & shear walls \\
D & & $15.00 \times 17.25$ & 11.00 & 3 & 2.99 & 4 & \\
E & $16.45 \times 18.05$ & 11.00 & 3 & 4.7 & 3 & \\
\hline
\end{tabular}

\section{METHODOLOGY}

Seismic vulnerability indicates the damage caused by a given level of risk, which is expressed as part of the value of the damaged items [1]. It can be assessed using various methods, which can be divided into two basic categories: empirical and analytical methods.

We estimated seismic vulnerability in a ways similar to the capacity spectrum method adopted in HAZUS [13], which involves constructing fragility curves and converting them to damage probability matrices, as well as constructing capacity curves (Figure 3 ).

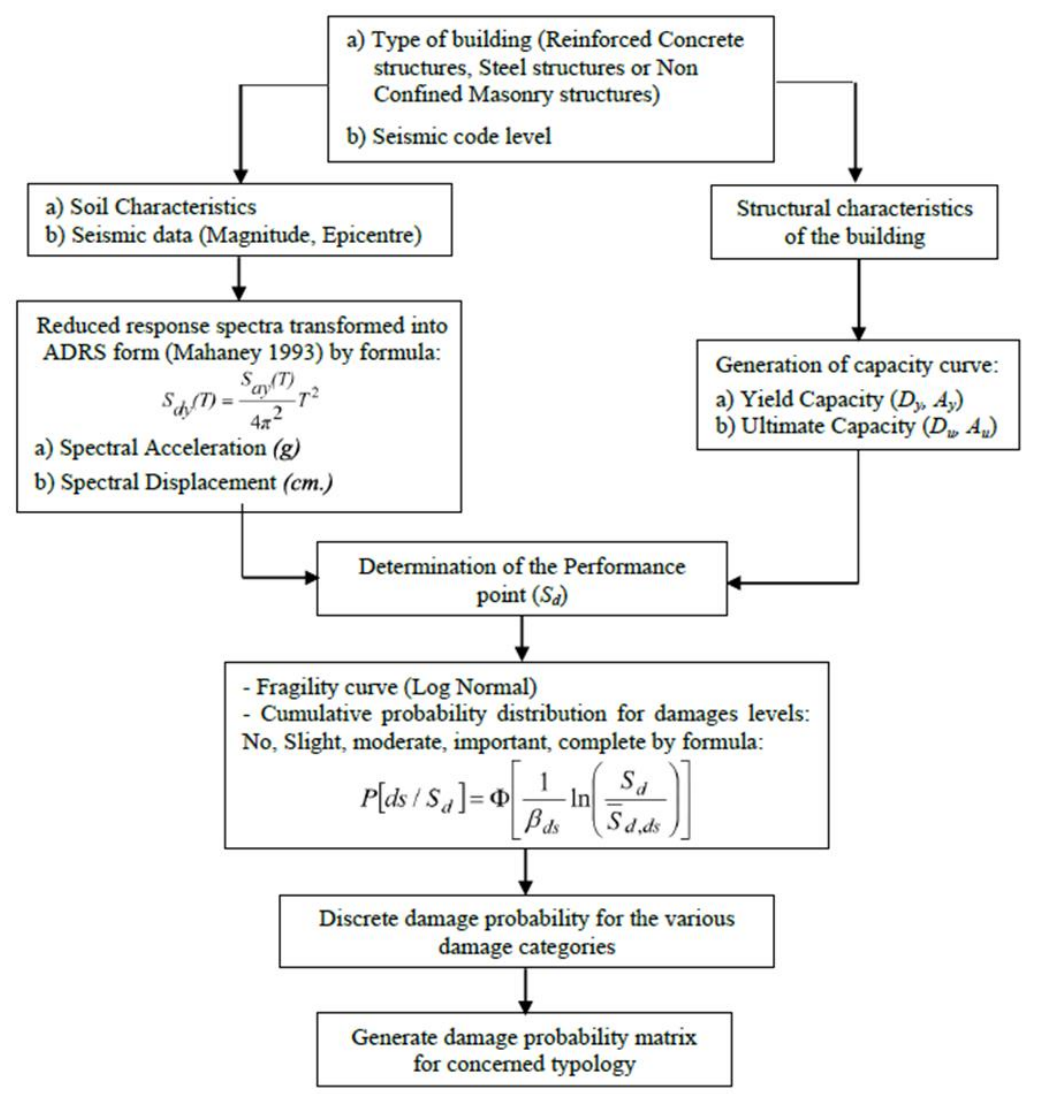

Figure 3 General process for evaluating seismic damage [14] 


\subsection{Building typology according HAZUS and the Risk-UE project}

To estimate building damage using fragility and capacity curves, it is necessary to define the model building type (including height) and the seismic design level representing the building or group of buildings, as well as the response spectrum at the building site.

HAZUS (Hazard-United States), developed in 1997 by the Federal Emergency Management Agency (FEMA), is the most significant and innovative methodology in the United States for assessing seismic damage [14]. It was initially dedicated to assessing seismic damage to structures and infrastructures [14], but since 2004 FEMA has incorporated other natural risks into the HAZUS model, which in February 2012 became the HAZUS Multi-Hazard Model in its latest version, HAZUS-MH 2.1 [15].

The HAZUS methodology uses 36 model building types, based on the FEMA 178 classification system and the NEHRP Handbook for the Seismic Evaluation of Existing Buildings. Table 2 shows the building typologies for RC buildings from the HAZUS approach.

A comprehensive typology of buildings in Europe has been developed as part of the Risk-UE Project (20012004), which distinguishes 17 types of buildings divided into three subclasses based on building height (low, medium, or high) and the seismic zone in which the building is located [8]. The European typology distinguishes three earthquake zones: Zone I, whose MMI (modified Mercalli scale) equals or exceeds earthquake intensity VIII; Zone II, which corresponds to MMI earthquake intensity VII; and Zone III, which corresponds to earthquake intensity VI. As shown in Table 2, Risk-UE considers both non-designed and code-designed buildings (with low, medium, and high ductility). There is also a classification for dual buildings [16], R4, but we did not have access to the fragility curve parameters for this classification.

Galista [11] compared the estimations of earthquake loss using the HAZUS and RISK-UE typologies, and we chose a typology similar to RISK-UE to represent our buildings. Even if we considered the buildings as RC frames, most buildings have a ratio of $1-2 \%$ between the shear wall area aligned in the considered direction of the periods and the plan area of a typical floor (Table 1), so we assume the seismic vulnerability to be greater than that for RC frames. Thus, we decided to estimate the seismic vulnerability for $\mathrm{C} 2 \mathrm{~L}$ buildings according to the HAZUS approach and for RC2-L buildings according to Risk-UE. We calculated the fundamental period of the buildings according to the EC 8 formula [17]:

$T=C_{t} \cdot H^{3 / 4}$

where $T$ is the fundamental period of vibration of the structure $(\mathrm{s})$ and $\mathrm{H}$ is height of the structure $(\mathrm{m})$.

For the structures with reinforced concrete or masonry bearing walls, $C_{t}$ may be calculated as follows:

$C_{t}=\frac{0,75}{\sqrt{A_{C}}}$

Then, Eq. (1) becomes:

$T=\frac{0,075}{\sqrt{A_{c}}} \cdot H^{0,75}$

with

$A_{c}=\sum A_{i}\left[0,2+\left(\frac{l_{w i}}{H}\right)^{2}\right]$

where $A_{c}$ is the total effective area of the shear walls on the first story $\left(\mathrm{m}^{2}\right), A_{i}$ is the effective cross-sectional area of shear wall $i$ in the considered direction on the first story $\left(\mathrm{m}^{2}\right)$, and $I_{w i}$ is length of shear wall $i$ on the first story parallel to the applied load $(\mathrm{m})$, with $\mathrm{I}_{\mathrm{wi}} / \mathrm{H} \leq 0.9$.

Though some of the buildings are mid-rise (4 stories), the fundamental period of RC shear walls is around $T=0.30 \mathrm{~s}$, and according to the European building typology [4], for RC2-L buildings the period is $T^{*}=0.43 \mathrm{~s}$, while for RC2-M buildings it is much greater, $T^{*}=0.64 \mathrm{~s}$, because mid-rise buildings have as many as 7 stories. To simplify the procedure, we present the seismic vulnerability according to the European typology estimated only for one building type: RC2-L (low-rise buildings, 1-3 floors) [4]. 
Table 2 Model building types according to HAZUS and Risk-UE

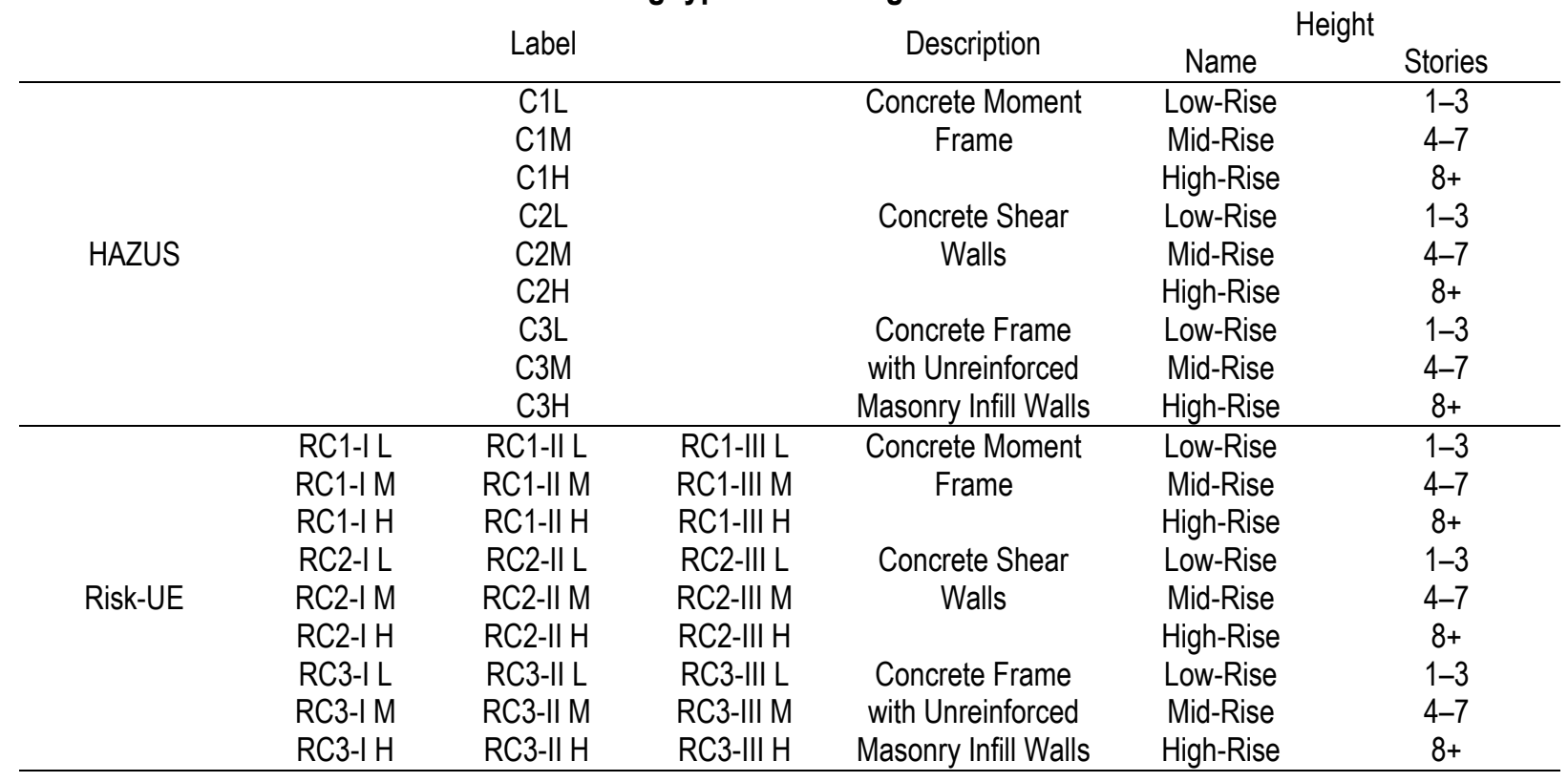

\subsection{Fragility curves}

Fragility curves express the probability that, at a given ground motion intensity, a given building class will reach or exceed a particular damage state [18].

Unfortunately, no fragility curves have been developed for Croatian building typologies. As such, for this study we constructed and analyzed the curves of probability of damage in accordance with HAZUS-MH-MR4 [13]. This approach relies on the assumption that the values follow a log-normal distribution curve so that the fragility curves are characterized by the median $\bar{S}_{d, d s}$ and standard deviation $\beta_{d s}$. For structural damage, given the spectral displacement $\left(S_{d}\right)$, the probability $(P)$ of meeting or exceeding a damage state $(d s)$ is modeled as follows [13]:

$P\left[d s / S_{d}\right]=\varphi\left[\frac{1}{\beta_{d s}} \cdot \ln \left(\frac{s_{d d}}{\bar{s}_{d, d s}}\right)\right]$,

where $\varphi$ is the standard normal cumulative distribution function.

The vulnerability damage states, for which fragility curves are constructed, typically represent the damage state or use limitation under the same conditions as the response of the structure. HAZUS distinguishes four damage states, as shown in Figure 4 [18]:

- Slight damage: Flexural or shear hairline cracks are present in some beams and columns near or within joints

- Moderate damage: Cracks are present in most beams and columns

- Extensive damage: Some elements of the frame reach their ultimate capacity

- Complete damage: The structure is demolished or will imminently be demolished 


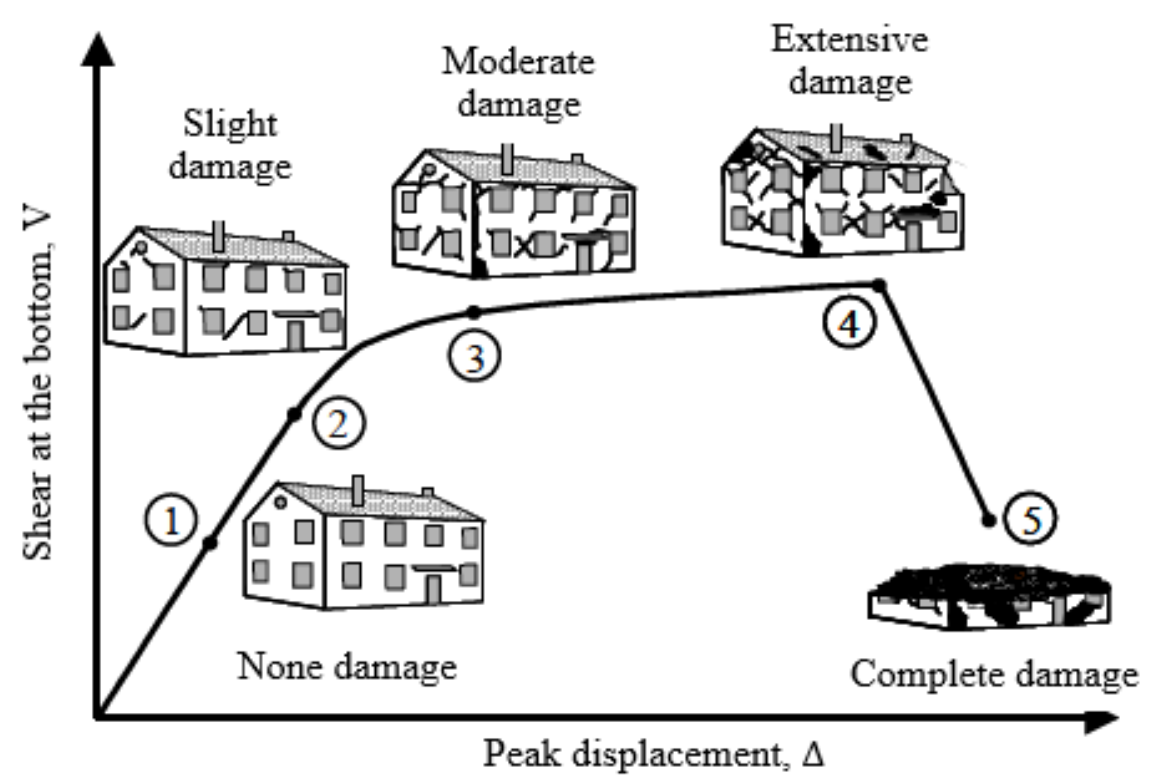

Figure 4 Illustration of the four damage states [18]

\subsection{Damage probability matrices}

To assess the seismic vulnerability of buildings to various damage levels, we converted the fragility curves into damage probability matrices (DPMs). Figure 5 shows an example of transforming fragility curves into DPMs. A key figure in evaluating seismic vulnerability is the performance point (PP), which is determined by capacity curves and spectrum acceleration and displacement in the AD format [19].
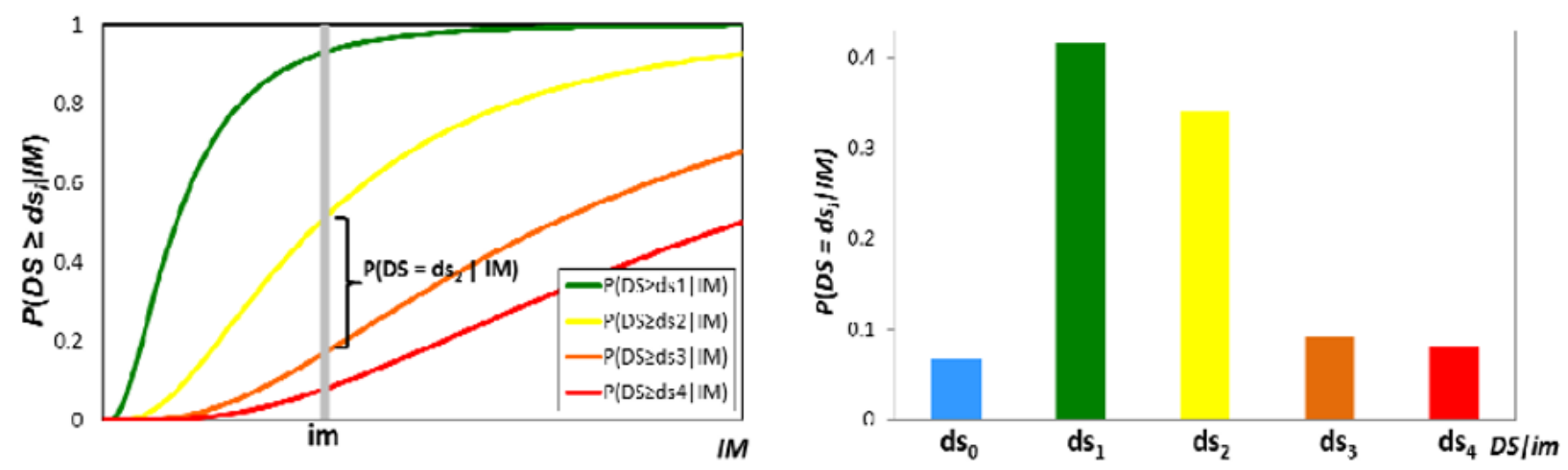

$\mathrm{ds}_{0}=$ None; $\mathrm{ds}_{1}=$ Slight $; \mathrm{ds}_{2}=$ Moderate $; \mathrm{ds}_{3}=$ Extensive; $\mathrm{ds}_{4}=$ Complete;

Figure 5 Constructing damage probability matrices from fragility curves [19]

\section{RESULTS}

The earthquake loss of buildings in Retfala Nova was estimated at three peak ground accelerations: $0.1 \mathrm{~g}, 0.2 \mathrm{~g}$, and $0.3 \mathrm{~g}$.

\subsection{Assessing the vulnerability of buildings}

The seismic vulnerability of an RC2-L building type at a peak acceleration of $0.1 \mathrm{~g}$ is assessed in three steps:

1. Construct capacity curves and determine the performance point (PP): Table 3 gives the values required for constructing the capacity curves. Figure 6 shows the idealized bilinear capacity curves and the performance point (PP) for the RC2-L building type required for converting the fragility curves into the DPMs. The intersection of the radial direction corresponding to the fundamental period of the building $(T)$, with the required elastic demand 
spectrum, determines the required elastic displacement. The intersection of the capacity curves and demand spectrum determines the acceleration of the yield, and it represents the required acceleration and capacity of the inelastic systems.

Table 3 Control points of capacity curves for the selected buildings (Risk-UE Project) [4]

\begin{tabular}{ccccccc} 
Ord. & Building type & Stories & $T[\mathrm{~s}]$ & $\mu$ & $D_{\mathrm{y}}[\mathrm{m}]$ & $A_{\mathrm{y}}[\mathrm{g}]$ \\
\hline 1. & RC2-L & 3 & 0.44 & 0.319 & 0.0186 & 0.3910 \\
\hline
\end{tabular}

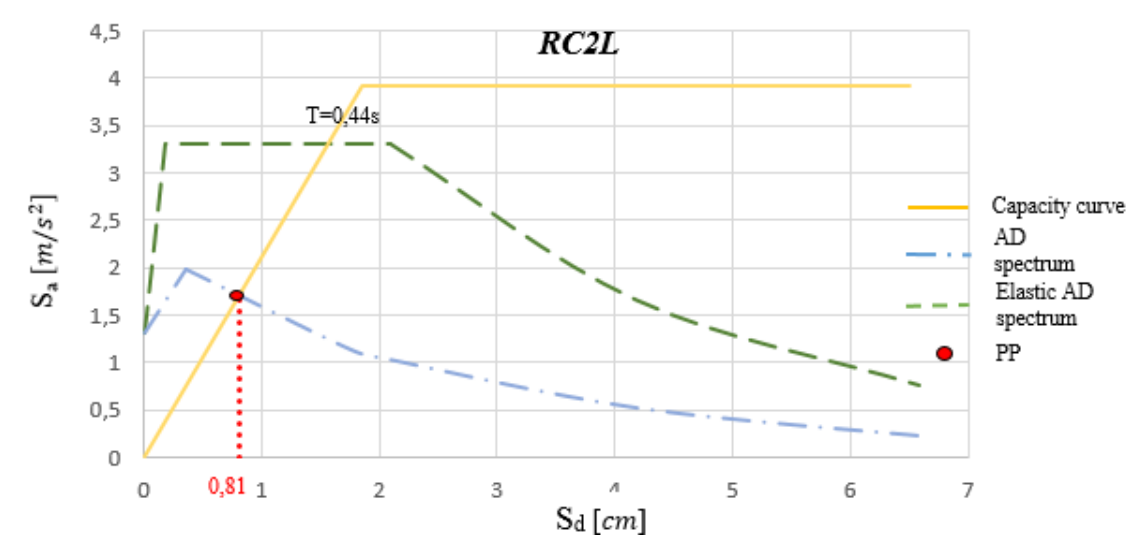

Figure 6 Bilinear idealized capacity curve and PP=0.81 cm for the RC2-L building type (ag=0.1g)

2. Construct fragility curves: Table 4 gives the parameters describing the fragility curves for the RC2-L building type. The median defined by the PP, obtained in the previous step, is determined, from which we calculated the probabilities of the damage levels.

Table 4 Parameters of fragility curves for the RC2-L building type in Osijek based on the European typology [4]

\begin{tabular}{|c|c|c|c|c|c|c|c|c|}
\hline \multirow{3}{*}{ Type of building } & \multicolumn{8}{|c|}{$\begin{array}{c}\text { typology [4] } \\
\text { Median }\left(S_{d}\right)[\mathrm{m}] \text { an }\end{array}$} \\
\hline & \multicolumn{2}{|c|}{ Slight } & \multicolumn{2}{|c|}{ Moderate } & \multicolumn{2}{|c|}{ Extensive } & \multicolumn{2}{|c|}{ Complete } \\
\hline & $S_{d_{d} g}$ & $\beta_{g}$ & $S_{d_{d u}}$ & $\beta_{u}$ & $S_{d, g}$ & $\beta_{e}$ & $S_{d, 0}$ & $\beta_{e}$ \\
\hline RC2-I-L & 0.027 & 0.88 & 0.058 & 0.88 & 0.099 & 0.88 & 0.159 & 0.88 \\
\hline
\end{tabular}

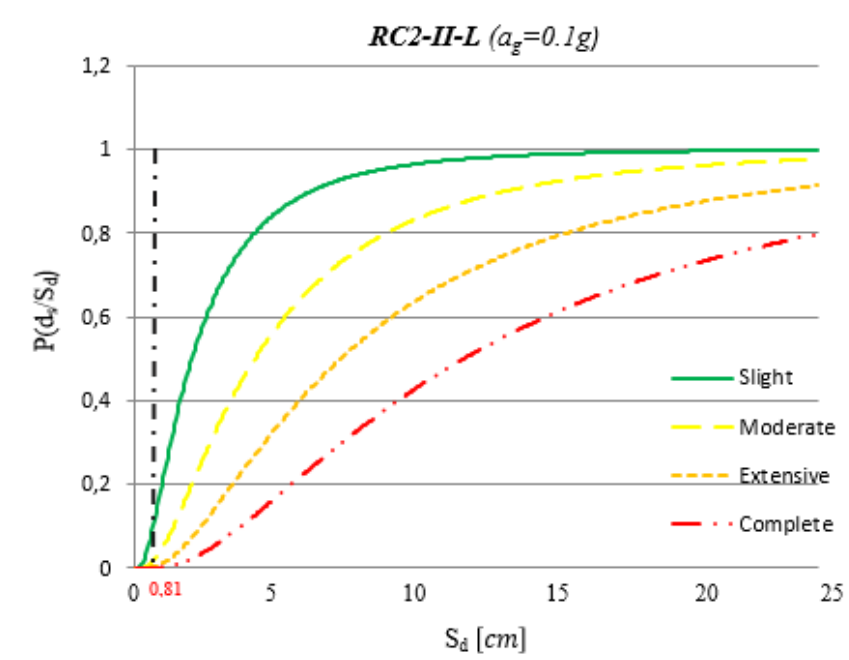

Figure 7 Bilinear idealized capacity curve with $P P=0.81 \mathrm{~cm}$ for the RC2-L building type $\left(a_{g}=0.1 \mathrm{~g}\right)$ 
3. Construct damage probability matrices: Figure 8 shows the damage probability matrices (DPMs) converted from the fragility curves. From these matrices, the probabilities of certain damage levels can be determined for a peak ground acceleration of $0.1 \mathrm{~g}$.

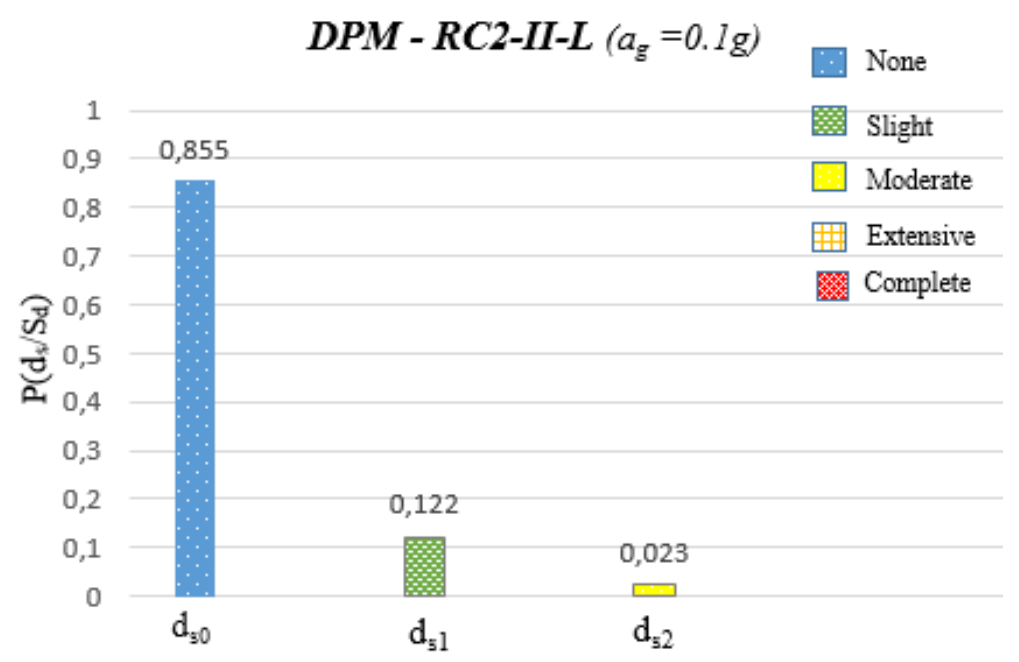

Figure 8 DPMs converted from the fragility curve for the RC2-II-L building type (ag= $0.1 \mathrm{~g}$ )

Using the same three steps, we estimated the seismic vulnerability for acceleration peaks of $0.2 \mathrm{~g}$ and $0.3 \mathrm{~g}$, and for building type RC2-II-L, as shown in Figure 9.
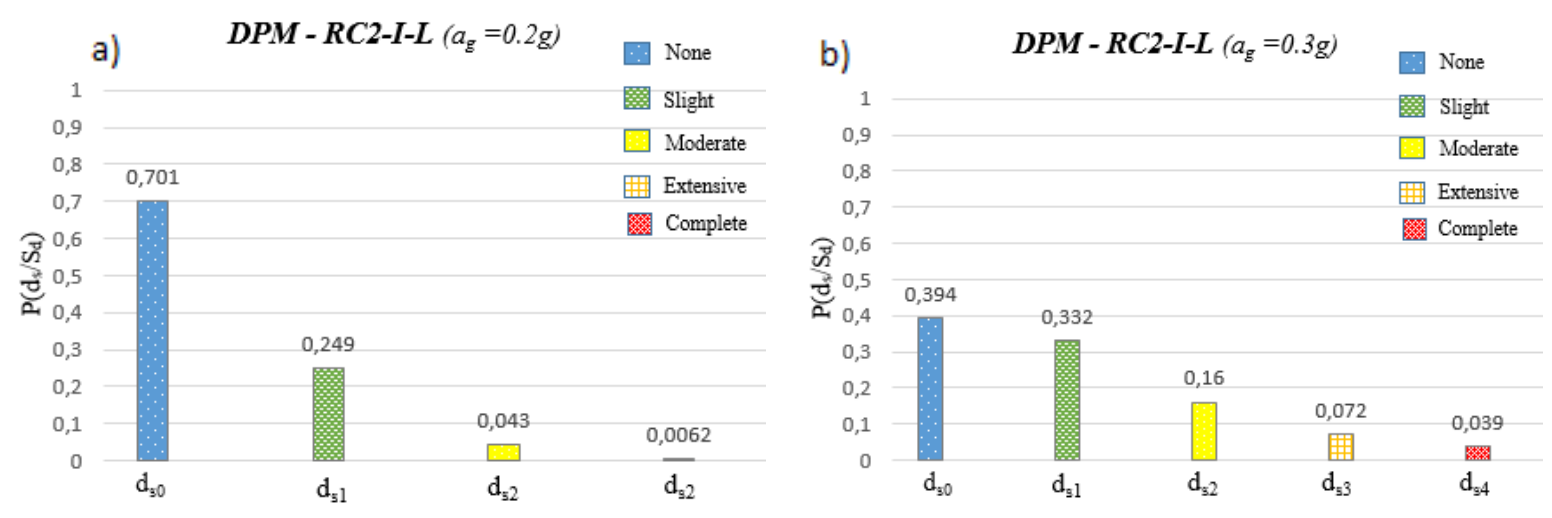

Figure 9 DPMs for the RC2-I-L building type for a) $a g=0.2 g$ and $b$ ) $a g=0.3 g$

At $0.1 \mathrm{~g}$, we expect no damage or perhaps slight damage (12.2\%) and moderate damage (2.3\%). At $0.2 \mathrm{~g}$, we expect light $(25 \%)$, moderate $(4.3 \%)$, and extensive $(0.6 \%)$ damage. At $0.3 \mathrm{~g}$, the probability of complete demolition is $3.9 \%$.

\subsection{Assessing loss using the European typology}

We analyzed the social and economic losses in a way similar to Aničic [20] for damage determined in accordance with the European typology. This estimate is based on an analysis of pre-earthquake data, such as the expected earthquake magnitude, population density, and geological and geotechnical properties of soil, as well as on knowledge of seismic resistance of buildings by type, age, condition, and other factors. These data may be more than sufficient to assess the damage to the buildings and the number of casualties (dead and injured) [20]. 


\subsubsection{Estimating losses in building stock}

Losses in the building stock are expressed as a percentage of devastation of the building stock as a proportion of its initial state, and can be calculated using the following equation [20]:

$$
(P U)=\sum_{i=1}^{n} B_{i} \cdot\left(\sum_{j=1}^{m} C_{i j} \cdot G_{i j}\right)
$$

where $B$ is the proportion of a certain structural system among all the residential buildings in a given city zone; $C$ is the percentage of damage to buildings of a certain structural system according to the damage levels for a given earthquake intensity and with respect to the total buildings in the system; and $G$ is the percentage of construction damage corresponding to a particular damage level in relation to the values for the $j$-damage of the $i$ structural system, where $i$ is the structural system and $j$ is the damage level.

Using Equation (6) for 20 residential buildings classified by the European typology, we found that for an earthquake of $\mathrm{VII}$ intensity $\left(a_{\mathrm{g}}=0.1 \mathrm{~g}\right)$, the proportion of complete destruction would be $0.47 \%$. Multiplying this value by the total area of buildings produces an area of complete destruction of $53.58 \mathrm{~m}^{2}$. An earthquake of $a_{g}=0.2 \mathrm{~g}$ should produce total losses of $1.23 \%$ and an area of complete destruction of $140.21 \mathrm{~m}^{2}$. An earthquake of $a_{\mathrm{g}}=0.3 \mathrm{~g}$ should produce the worst damage of $9.8 \%$ and an area of complete destruction of $1117.41 \mathrm{~m}^{2}$. Figure 10 shows the losses per square meter for the three earthquake intensities.

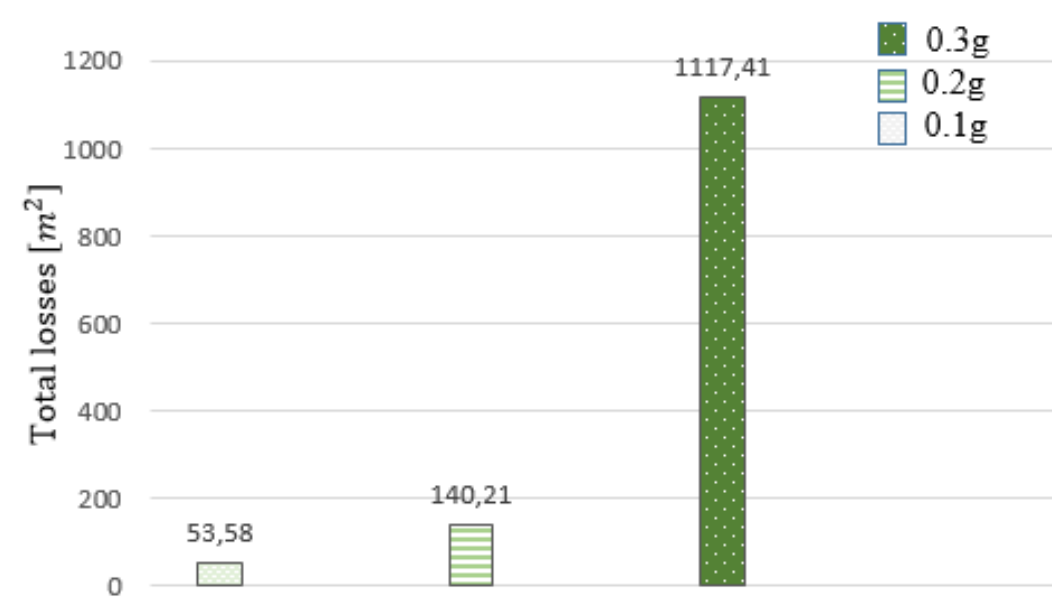

Figure 10 Total losses per square meter for the three peak ground accelerations

\subsubsection{Estimating the number of victims}

The earthquake victims include both injured and dead people. We calculated the number of injured people with Equation (7) [20] and the number of dead people with Equation (8):

$$
(N I)=A \cdot \sum_{i=1}^{n} B_{i} \cdot\left(\sum_{j=1}^{m} C_{i j} \cdot D_{i j}\right)
$$

$(N D)=A \cdot \sum_{i=1}^{n} B_{i} \cdot\left(\sum_{j=1}^{m} C_{i j} \cdot E_{i j}\right)$

where $A$ is the total number of people living in a given area; $B$ and $C$ are the same as in Equation (6); $D$ is the percentage of injured for the $j$-damage in the $i$-structural system; $E$ is the percentage of dead for the $j$-damage in the $i$-structural system; and $i, j, m$, and $n$ are the same as in Equation (6).

We calculated the total people living in Retfala Nova by using the national Croatian average for people living in one housing unit: 3.1 people. This led to a figure of 125 people living in the 20 residential settlements.

Using Equations (7) and (8), we conclude that an earthquake of intensity VII will injure or kill no one-more precisely, $0.03 \%$ of injured habitants. A peak ground acceleration $a_{g}=0.2 \mathrm{~g}$ should injure one person, and $a_{g}=0.3 g$ should injure six people and kill two people at most (Figure 11). 


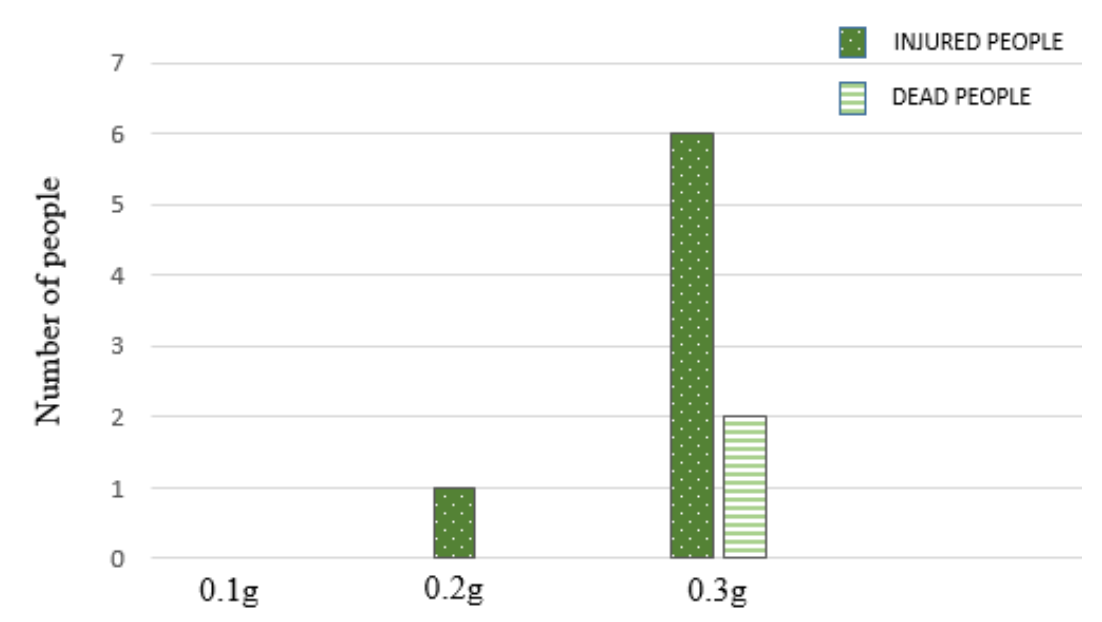

Figure 11 Calculated losses at three peak ground accelerations

\section{CONCLUSION}

In this study, we presented a form used to collect information on buildings in order to create a building database of the predominant building typology in Osijek, which allowed us to define their exposure, an important step in assessing earthquake loss. Then, we estimated seismic damage for three values of peak ground acceleration $(0.1 \mathrm{~g}, 0.2 \mathrm{~g}$, and $0.3 \mathrm{~g})$, considering the buildings by using the HAZUS approach, adapting the capacity and fragility curves of related typologies to fit our building typologies.

Our assessment of losses in building stock and the numbers of injured and dead people should not be considered to be completely accurate because our analysis has several assumptions and uncertainties. For example, we did not know the exact number of people living in the settlement. Also, the typology of these buildings should be investigated further because it is not clear whether they should be considered RC frames, RC shear wall buildings, or dual buildings, and the loss assessments generated for these structural types should be compared.

\section{References}

[1] Anagostopolous, S. A.; Petrovski, J.; Bouwkamp, J. G. 1998: Emergency Earthquake Damage and Usability Assessment of Buildings, Earthquake Spectra, 5(3), pp. 461-476. http://dx.doi.org/10.1193/1.1585535

[2] ATC-40, 1996: Seismic Evaluation and Retrofit of Concrete Buildings, Applied Technology Council, Report ATC-40, Redwood City, California.

[3] FEMA 1999: HAZUS99 user and technical manuals. Federal Emergency Management Agency Report: HAZUS 1999, Washington D.C., USA.

[4] ELER 2010: Technical Manual, Earthquake Loss Estimation Routine, Bogazici University, Department of Earthquake Engineering, Istanbul, 2010.

[5] Kircher, C.; Whitman, R.; Holmes, W. 2006: HAZUS Earthquake Loss Estimation Methods, Natural Hazards Review, 7:2(45), pp. 45-59. http://dx.doi.org/10.1061/(ASCE)1527-6988(2006)7:2(45)

[6] Molina, S.; Lindholm, C. 2005: A Logic Tree Extension of the Capacity Spectrum Method Developed to Estimate Seismic Risk in Oslo, Norway, Journal Earthquake Engineering, 9(6), pp. 877-897. http://dx.doi.org/ 10.1142/S1363246905002201

[7] Lantada, N.; Pujades, L. G.; Barbat, A. H. 2009: Vulnerability index and capacity spectrum based methods for urban seismic risk evaluation. A comparison. Natural Hazards, 51, pp. 501-524. http://dx.doi.org/10.1007/s11069-007-9212-4

[8] Boukri, M.; Farsi, M. N.; Mebarki, A.; Belazougui, M.; · Amellal, O.; Mezazigh, B.; Guessoum, N.; Bourenane, H.; Benhamouche, A. 2014: Seismic risk and damage prediction: case of the buildings in 
Constantine city (Algeria), Bulletin of Earthquake Engineering, 12, pp. 2683-2704. http://dx.doi.org/10.1007/s10518-014-9594-0

[9] Mouroux, P.; Bertrand, E.; Bour, M.; Le Brun, B.; Depinois, S.; Masure, P. 2004: The European RISK-UE project: an advanced approach to earthquake risk scenarios, Proc. of the 13th World Conference on Earthquake Engineering, Vancouver, BC, Canada, Paper No. 3329.

[10] Brzev, S.; Scawthorn, C.; Charleson, A. W.; Allen, L.; Greene, M.; Jaiswal, K.; Silva, V. 2013: Exposure Modelling, GEM Building Taxonomy V2.0, Global Earthquake Model GEM, GEM Technical Report 2013-02 V1.0.0, Available online: http://www.globalquakemodel.org/media/publication/EXP-MOD-GEM-BuildingTaxonomy-201302-V01_1.pdf, Accessed 28 April 2015.

[11] Galista, M. 2015: Seismic risk assessment of buildings in Retfala Nova in Osijek, Graduate Thesis, University J.J.Stzrossmayer in Osijek, Civil Engineering Faculty Osijek (in Croatian).

[12] Catalogue Škojo immovables, Osijek settlement "Retfala Nova", Available online: www.retfalanova.hr, Accessed 22 September 2014.

[13] Federal Emergency Management Agency (FEMA) 2003: HAZUS-MH Technical Manual, Federal Emergency Management Agency, Washington, DC, U.S.A., Available online: http://www.fema.gov/media-librarydata/20130726-1716-25045-6422/hazus_mr4_earthquake_tech_manual.pdf, Accessed 27 March 2015.

[14] Boukri, M.; Farsi, M. N.; Mébarki, A.; Belazougui, M. 2013: Development of an integrated approach for Algerian building seismic damage assessment, Structural Engineering and Mechanics, 47(4), pp. 471-493. http://dx.doi.org/10.12989/sem.2013.47.4.471

[15] National Institute of Building Sciences website, NIBS 2012: Multi-hazard risk assessment/HAZUS, Washington, DC, United States, Available online: file:///C:/Users/Korisnik/Downloads/nps49-01271103\%20(1).pdf

[16] SYNER-G 2013: Reference Report 4, Guidelines for deriving seismic fragility functions of elements at risk: Buildings, lifelines, transportation networks and critical facilities, Amir M. Kaynia, Ed., 2013.

[17] EN 1998-1:2004, Eurocode 8: design of structures for earthquake resistance - part 1: general rules, seismic actions and rules for buildings. European Committee for Standardization, 2004.

[18] Erduran, E.; Magsi, A.M.; Gill, A. W. M.; Lindholm, C. 2012: Earthquake risk assessment of Quetta, Kjeller, Norway, Available online: http://www.pmd.gov.pk/seismic/3.pdf, Accessed 26 July 2015.

[19] D’Ayala, D.; Meslem, A.; Vamvatsikos, D.; Porter, K.; Rossetto, T.; Crowley, H.; Silva, V. 2014: Guidelines for analytical vulnerability assessment of low/mid-rise buildings, Global Earthquake Model, Available online: www.nexus.globalquakemodel.org/gem-vulnerability/posts/, Accessed 12 July 2015.

[20] Aničić, D. 1992: Damage assessment to the building stock and the number of victims of possible future earthquake, Civil Defence, 1(2), pp. 135-143 (in Croatian). pp. 1814-1820. 